\title{
RANCANG BANGUN APLIKASI PEMBAYARAN SEKOLAH MENGGUNAKAN JAVA DAN MYSQL BERBASIS CLIENT SERVER DI SMA YOS SUDARSO CILACAP
}

\author{
Elisa Usada ${ }^{1}$, Anggun Fitrian Isnawati ${ }^{2}$, Dewi Fatimah ${ }^{3}$ \\ ${ }^{1,2,3}$ Program Studi Diploma III Teknik Telekomunikasi, Purwokerto \\ elisa@akatelsp.ac.id, ${ }^{2}$ anggun_fitrian@yahoo.com, ${ }^{3}$ dewiclp_d307168@yahoo.co.id
}

\begin{abstract}
Abstrak
SMA Yos Sudarso merupakan salah satu sekolah yang sudah memanfaatkan komputer untuk menyelesaikan berbagai macam tugas, tetapi pemanfaatannya masih belum maksimal karena ada bagian administrasi yang masih menggunakan metode manual, yaitu pada administrasi pembayaran. Penelitian ini berusaha membuat sebuah aplikasi client server berteknologi JAVA dan MySQL untuk mengelola data pembayaran sekolah meliputi pembayaran SPP, pembayaran uang gedung serta pembayaran ujian. Metode waterfall digunakan sebagai acuan perancangan dan pengembangan aplikasi. Alat abstraksi sistem yang digunakan adalah use case diagram dan class diagram. Perancangan basis data dengan menggunakan ERD. Pengujian dilakukan dengan metode black box yaitu hanya menguji jalannya fungsi-fungsi yang telah direncanakan tanpa mempedulikan aspek proses internal dalam kode dan algoritma. Pengujian memberikan hasil bahwa aplikasi dapat dijalankan secara client server dan fungsi dapat berjalan semestinya. Proses back up data otomatis menjadi kekurangan dari aplikasi dalam penelitian ini.
\end{abstract}

Kata kunci : aplikasi pembayaran, JAVA dan MySQL

\section{Pendahuluan}

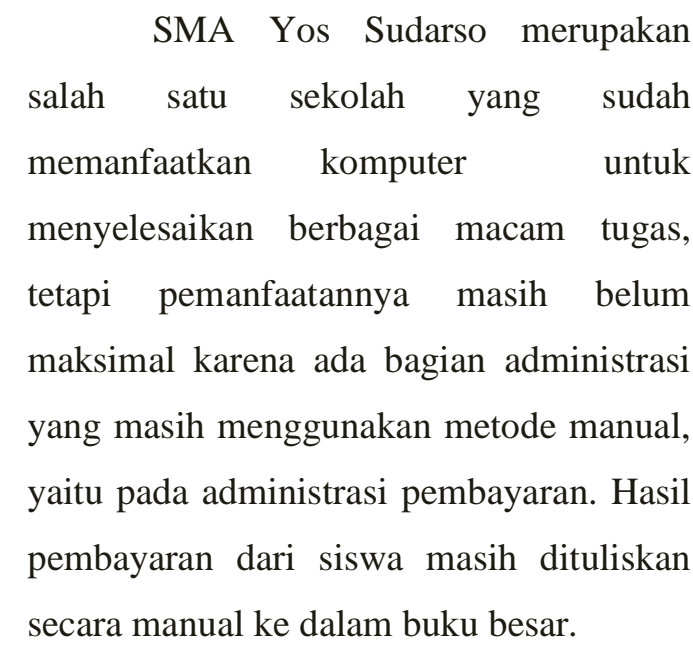

Penelitian ini berusaha membuat sebuah aplikasi berteknologi JAVA dan MySQL untuk mengelola data pembayaran sekolah seperti, input data siswa, pencarian data siswa, report dari pembayaran siswa, serta pencetakan bukti pembayaran. Proses pembayaran yang akan dilibatkan dalam aplikasi adalah pembayaran SPP, pembayaran uang gedung serta pembayaran ujian. Aplikasi ini akan diterapkan secara client server pada komputer yang berada di ruang kepala sekolah, kepala tata usaha dan ruang bendahara. Kepala sekolah dan kepala tata usaha menggunakan aplikasi ini untuk melihat informasi laporan pembayaran jika sewaktu-waktu diperlukan. Bendahara menggunakan aplikasi ini untuk mengelola data pembayaran sekolah seperti, input data siswa, pencarian data siswa, report dari pembayaran siswa, serta pencetakan bukti pembayaran.

Perancangan dan pembangunan aplikasi dalam penelitian ini menggunakan metodologi waterfall dengan tahapan sebagai berikut (Sommerville, 2009): 
a. Requirement analysis and definition, mengumpulkan kebutuhan secara lengkap kemudian dianalisis dan didefinisikan kebutuhan yang harus dipenuhi oleh program yang akan dibangun.

b. System and software design, desain dikerjakan setelah kebutuhan selesai dikumpulkan secara lengkap. Alat perancangan yang digunakan adalah UML (Unified Modelling Language) untuk merancang objek dalam program, beserta ERD (Entity Relationship Diagram) untuk merancang kebutuhan basis data.

c. Implementation and unit testing, desain program diterjemahkan ke dalam bahasa pemrograman yang sudah ditentukan, yaitu JAVA.

d. Integration and system testing, penyatuan unit-unit kemudian diuji secara keseluruhan (system testing) menggunakan emulator.

e. Operation and maintenance, mengoperasikan program di perangkat yang sesungguhnya.

\section{Bahasa Pemrograman JAVA dan Netbeans IDE}

\subsection{JAVA}

JAVA merupakan bahasa pemrograman yang berorientasi objek dan dapat dijalankan pada berbagai platform sistem operasi. JAVA dikembangkan oleh Sun Microsystem Inc. Perkembangan Java tidak hanya terfokus pada satu sistem operasi, tetapi dikembangkan untuk berbagai sistem operasi dan bersifat open source. Fitur penting bahasa JAVA adalah (Hariyanto, 2007):

a. Bahasa sederhana, tidak menyediakan fitur-fitur rumit dan secara otomatis dapat melakukan dealokasi memori.

b. Bahasa pemrograman berorientasi objek, program dipandang sebagai sekelompok objek yang saling berinteraksi.

c. Bahasa statically typed, seluruh objek dalam JAVA harus dideklarasikan terlebih dahulu.

d. Bahasa dikompilasi, kompilasi dilakukan dengan JAVA compiler dan menghasilkan bytecode yang memiliki fungsi serupa dengan kode mesin.

e. Bahasa yang aman, JAVA menyediakan berbagai teknik pengamanan misalnya dengan peniadaan pointer, penggunaan three layer security model, adanya JAVA verifier dan pembatasan kerja applet.

f. Independen terhadap platform, tipe data dalam JAVA memiliki ukuran yang sama meskipun dijalankan pada platform yang berbeda-beda.

g. Multithreading, dapat mempunyai lebih dari satu thread eksekusi pada saat yang sama sehingga memungkinkan program menangani tugas secara konkuren.

h. Mendukung garbage collector, pemrogram tidak perlu menghapus sendiri objek-objek yang tidak digunakan lagi. 
i. Tangguh, JAVA interpreter memeriksa semua akses sistem yang dilakukan sehingga tidak menyebabkan crash pada sistem.

j. Mampu diperluas, mendukung native method sehingga fungsi dapat ditulis dalam bahasa lain.

k. 2.2 Netbeans IDE

1. NetBeans mengacu pada dua hal, yakni platform untuk pengembangan aplikasi desktop Java dan sebuah IDE (Integrated Development Environment) yang dibangun menggunakan platform NetBeans. Platform NetBeans memungkinkan aplikasi dibangun dari sekumpulan komponen perangkat lunak moduler yang disebut 'modul'. Sebuah modul adalah suatu arsip Java (Java archive) yang memuat kelas-kelas Java untuk berinteraksi dengan NetBeans Open API dan file manifestasi yang mengidentifikasinya sebagai modul. Aplikasi yang dibangun dengan modul dapat dikembangkan dengan menambahkan modul baru. Netbeans IDE yang digunakan dalam penelitian ini adalah Netbeans 6.5.1.

\section{MySQL}

MySQL merupakan DBMS (Database Management System) yang bersifat open source yaitu kode yang dipakai untuk membuat MySQL dapat dijalankan secara langsung dalam sistem operasi dan dapat diunduh secara gratis di internet. MySQL awalnya dibuat oleh perusahaan konsultan bernama TcX yang berlokasi di Swedia. Fitur-fitur dalam MySQL adalah sebagai berikut (Kadir, 2008):

a. Multiplatform

MySQL tersedia pada beberapa platform seperti Windows, Linux, Unix, dan lain sebagainya.

b. Andal, cepat, dan mudah digunakan MySQL tergolong sebagai server basis data (server yang melayani permintaan terhadap basis data) yang andal, dapat menangani basis data yang besar dengan kecepatan tinggi, mendukung banyak sekali fungsi untuk mengakses basis data, dan mudah digunakan.

c. Jaminan keamanan akses

MySQL mendukung pengamanan basis data dengan berbagai kriteria pengaksesan. Sebagai gambaran, dimungkinkan untuk mengatur user tertentu agar bisa mengakses data yang bersifat rahasia. MySQL juga mendukung konektivitas ke berbagai software, misalnya dengan menggunakan ODBC (Open Database Connectivity).

d. Dukungan SQL MySQL mendukung perintah SQL (Structured Query Language). SQL merupakan standar dalam pengaksesan basis data relasional.

\section{Client Server \\ LAN (Local Area Network) adalah sejumlah komputer yang dihubungkan bersama di dalam suatu areal tertentu yang}


tidak begitu luas, seperti di dalam satu kantor atau gedung. LAN tersusun dari beberapa elemen dasar yaitu hardware dan software. Salah satu tipe LAN adalah client-server.

Client-server adalah suatu bentuk arsitektur, dimana client adalah perangkat penerima yang akan menampilkan dan menjalankan aplikasi (software komputer) dan server adalah perangkat yang menyediakan dan bertindak sebagai pengelola aplikasi, data, dan keamanannya. Server biasanya terhubung dengan client melalui kabel UTP dan sebuah kartu jaringan (network card). Kartu jaringan ini biasanya berupa kartu PCI atau ISA.

Client-server merujuk kepada cara mendistribusikan aplikasi ke pihak client dan pihak server. Dalam model clientserver, sebuah aplikasi dibagi menjadi dua bagian yang terpisah (tetapi masih dalam sebuah kesatuan) yakni komponen client dan komponen server. Komponen client dijalankan pada sebuah workstation. Pemakai workstation memasukkan data dengan menggunakan teknologi pemrosesan tertentu, kemudian mengirimkannya ke komponen server, umumnya berupa permintaan layanan tertentu yang dimiliki oleh server. Komponen server akan menerima permintaan layanan tersebut dan langsung memprosesnya serta mengembalikan hasil pemrosesan kepada client. Client pun menerima informasi hasil pemrosesan data tadi dan menampilkannya kepada pemakai dengan menggunakan aplikasi yang digunakan oleh pemakai.

Client-server merupakan penyelesaian masalah pada software yang menggunakan basis data sehingga setiap komputer tidak perlu diinstal database. Dengan metode client-server, database dapat diinstal pada komputer server dan aplikasinya diinstal pada client. Komponen client juga sering disebut sebagai front-end, sedangkan komponen server disebut sebagai backend.

\section{5. $U M L$}

UML (Unified Modelling Language) adalah sebuah bahasa yg telah menjadi standar dalam industri untuk visualisasi, merancang dan mendokumentasikan sistem piranti lunak. UML menggunakan class dan operation dalam konsep dasarnya, maka UML lebih cocok untuk penulisan piranti lunak dalam bahasabahasa berorientasi objek seperti $\mathrm{C}++$, Java, C\# atau VB.NET. Walaupun demikian, UML tetap dapat digunakan untuk memodelkan aplikasi prosedural dalam VB atau C.

UML terdiri dari diagram-diagram yang merupakan sekumpulan bentuk khusus untuk menggambarkan berbagai diagram piranti lunak. Diagram UML yang digunakan dalam penelitian ini adalah use case dan class diagram.

\subsection{Diagram Use Case}

Use case diagram menggambarkan fungsionalitas yang diharapkan dari sebuah 
sistem. Yang ditekankan adalah "apa" yang diperbuat sistem, dan bukan "bagaimana". Sebuah use case merepresentasikan sebuah interaksi antara aktor dengan sistem. Use case merupakan sebuah pekerjaan tertentu, misalnya login ke sistem, menambah sebuah daftar belanja, dan sebagainya. Seorang atau sebuah aktor adalah sebuah entitas manusia atau mesin yang berinteraksi dengan sistem untuk melakukan pekerjaanpekerjaan tertentu.

\subsection{Diagram Class}

Class diagram menggambarkan struktur dan deskripsi class, package dan objek serta hubungan satu sama lain seperti containment, pewarisan, asosiasi, dan lainlain. Jenis hubungan antar Class dalam UML adalah sebagai berikut:

a. Asosiasi, yaitu hubungan statis antar class. Umumnya menggambarkan class yang memiliki atribut berupa class lain, atau class yang harus mengetahui eksistensi class lain. Panah navigability menunjukkan arah query antar class.

b. Agregasi, yaitu hubungan yang menyatakan bagian ("terdiri atas..").

c. Pewarisan, yaitu hubungan hirarkis antar class. Class dapat diturunkan dari class lain dan mewarisi semua atribut dan metode class asalnya dan menambahkan fungsionalitas baru, sehingga ia disebut anak dari class yang diwarisinya. Kebalikan dari pewarisan adalah generalisasi. d. Hubungan dinamis, yaitu rangkaian pesan (message) yang di-passing dari satu class kepada class lain.

\section{ERD}

ERD merupakan notasi grafis dalam pemodelan data yang mendeskripsikan hubungan antara penyimpanan. ERD digunakan untuk memodelkan struktur data dan hubungan antar data. Istilah-istilah penting dalam ERD :

\section{a. Entity}

Adalah suatu objek yang dapat diidentifikasi dalam lingkungan pemakai, sesuatu yang penting bagi pemakai dalam konteks sistem yang akan dibuat. Sebagai contoh pelanggan, pekerja dan lain-lain. Seandainya A adalah seorang pekerja maka A adalah isi dari pekerja. Karena itu harus dibedakan antara entiti sebagai bentuk umum dari deskripsi tertentu dan isi entiti seperti A dan B dalam contoh di atas. Entity digambarkan dalam bentuk persegi empat. Contoh Entity dapat dilihat pada Gambar 1.

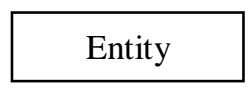

Gambar 1 Entity

\section{b. Atribut}

Entity mempunyai elemen yang disebut atribut, dan berfungsi mendeskripsikan karakter entity. Misalnya atribut kode_barang dari entity barang. Setiap entity dapat memiliki lebih dari satu atribut. Atribut digambarkan dalam bentuk 
ellips. Contoh atribut dapat dilihat pada

Gambar 2.

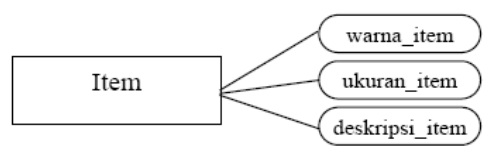

Gambar 2 Atribut

c. Hubungan

Dalam hubungan harus dibedakan antara bentuk hubungan antar entity dengan isi dari hubungan itu sendiri. Misalnya dalam kasus hubungan antara entity siswa dan entity mata_kuliah adalah mengikuti, sedangkan isi hubungannya dapat berupa nilai_ujian. Hubungan digambarkan dalam bentuk intan atau diamonds. Contoh hubungan dalam ERD dapat dilihat pada Gambar 3.

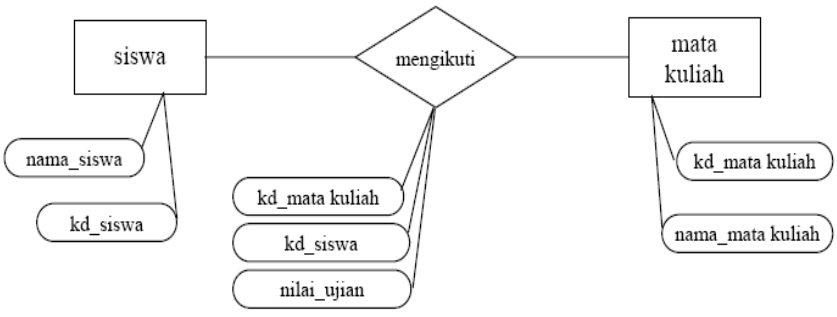

Gambar 3 Contoh hubungan dalam ERD

Jenis-jenis hubungan dalam ERD:

1) Satu ke satu (one to one), misalnya dalam suatu perusahaan mempunyai aturan satu supir hanya boleh menangani satu kendaraan karena alasan tertentu. Hubungan one to one dapat dilihat pada Gambar 4.

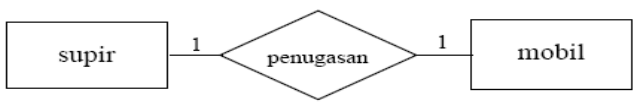

Gambar 4 Contoh hubungan one to one
2) Satu ke banyak (one to many), misalnya suatu sekolah selalu mempunyai asumsi bahwa satu kelas terdiri dari banyak siswa tetapi tidak sebaliknya, yaitu satu siswa tidak dapat belajar pada kelas yang berbeda. Hubungan one to many dapat dilihat pada Gambar 5.

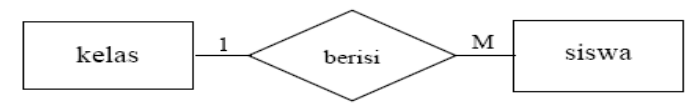

Gambar 5 Contoh hubungan one to many

3) Banyak ke banyak (many to many), misalnya suatu sekolah mempunyai asumsi bahwa siswa mendapatkan banyak mata pelajaran sedangkan mata pelajaran diikuti oleh banyak siswa. Hubungan many to many dapat dilihat pada Gambar 6.

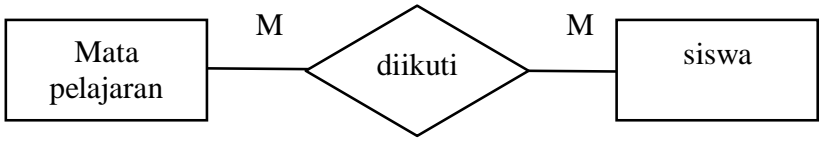

Gambar 6 Contoh hubungan many to many

Aturan dalam ERD:

1) Memilih kunci record : dari daftar kamus data, memilih field yang akan digunakan sebagai kunci record.

2) Membentuk entity berdasarkan kunci record.

3) Mencari relasi antar tabel dan menggabungkannya.

\section{Rancangan dan Implementasi}

\subsection{Analisis Sistem}

Pada tahap analisis sistem dilakukan pengumpulan data-data yang diperlukan 
dalam pembuatan aplikasi pembayaran sekolah. Metode pengumpulan data yang telah dilakukan adalah sebagai berikut:

a. Wawancara, yaitu melakukan tanya jawab secara langsung dengan pihakpihak yang bersangkutan.

b. Observasi, yaitu melakukan pengamatan dan melihat catatan yang dibutuhkan.

Dokumentasi cara kerja sistem pembayaran manual yang berada di SMA Yos Sudarso Cilacap perlu dilakukan dalam tahapan ini untuk mengidentifikasi alur proses dan aliran data yang diperlukan. Berdasarkan hasil wawancara dan observasi didapatkan alur proses pembayaran yang berjalan di SMA Yos Sudarso Cilacap adalah sebagai berikut:

a. Proses pembayaran siswa meliputi proses pembayaran SPP, uang gedung dan uang ujian.

b. Proses pembayaran SPP dari siswa dimulai dengan penyerahan kartu SPP oleh siswa, kemudian pencatatan pembayaran dari siswa oleh petugas administrasi ke dalam buku besar. Setelah itu, petugas menyerahkan bukti pembayaran kepada siswa.

c. Proses pencarian data pembayaran siswa dilakukan dengan cara mencari data pembayaran siswa per kelas satu per satu pada buku besar sesuai dengan yang dibutuhkan.

d. Proses pelaporan data pembayaran siswa dilakukan dengan mengumpulkan semua data pembayaran siswa tiap kelas yang berada dalam buku besar setiap bulan, semester, dan tahun.

Perangkat keras yang akan digunakan sebagai implementasi sistem pembayaran terkomputasi adalah perangkat keras yang sudah ada di instansi SMA Yos Sudarso Cilacap. Spesifikasi perangkat keras yang berada pada SMA Yos Sudarso Cilacap adalah tiga buah PC (Personal Computer) dengan:

a. Processor Intel Pentium 4

b. RAM (Random Acces Memory) 256 $\mathrm{Mb}$

\section{c. Hardisk $40 \mathrm{~Gb}$}

\subsection{Perancangan Sistem}

Tahap perancangan sistem ini menggunakan use case diagram dan class diagram. Use case diagram dapat dilihat pada Gambar 7.

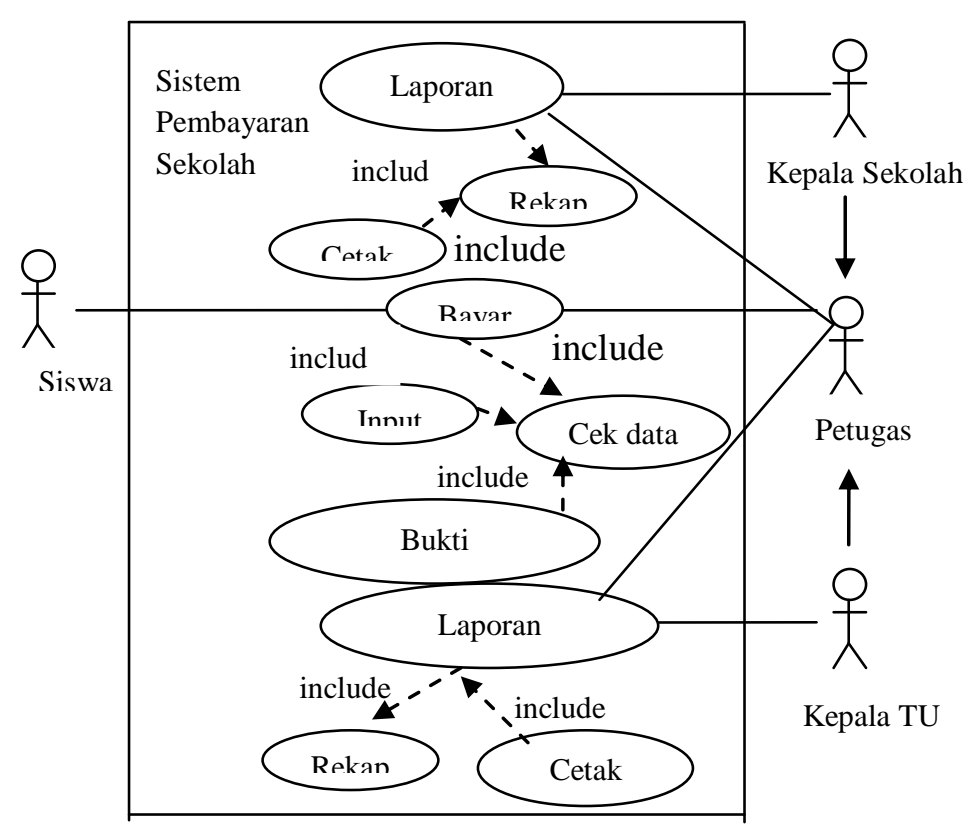

Gambar 7 Use Case Diagram 


\subsection{Perancangan Basis Data}

\subsubsection{ERD}

a. Langkah 1 (menentukan entity)

Siswa, bagi kelas, kelas

Siswa, SPP

Siswa, Uang gedung

Siswa, Uang ujian

b. Langkah 2 (menggambarkan entity)

\begin{tabular}{|l|l|}
\hline Siswa & Bagi Kelas \\
\hline
\end{tabular}

Gambar 8 Entity Siswa dengan Bagi kelas

Siswa

SPP

Gambar 9 Entity Siswa dengan SPP

Siswa

Uang Gedung

Gambar 10 Entity Siswa dengan Uang Gedung

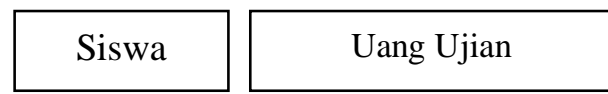

Gambar 11 Entity Siswa dengan uang Ujian

c. Langkah 3 (menggambar relasi)

d. Melengkapi dengan atribut kunci dan atribut lainnya

ERD siswa dengan bagi kelas dapat dilihat pada Gambar 12.

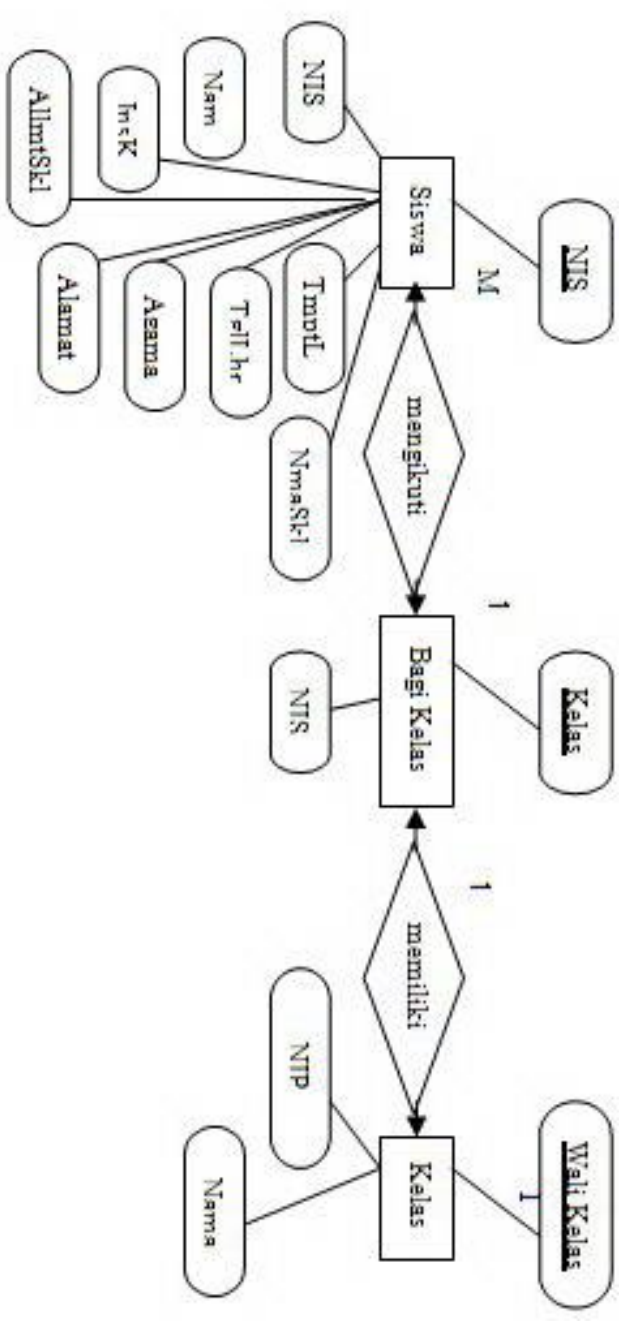

Gambar 12 ERD Siswa dengan Bagi Kelas ERD siswa dengan uang SPP dapat dilihat pada Gambar 13. 


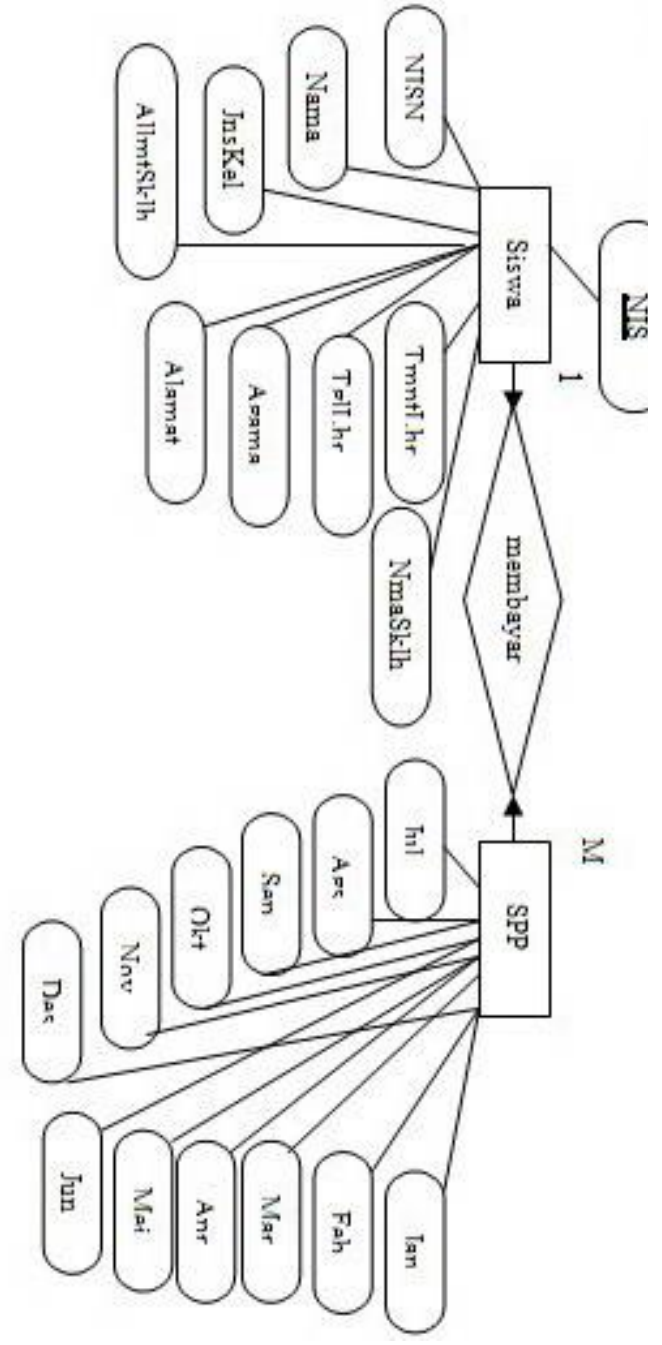

Gambar 13 ERD Siswa dengan Uang SPP

ERD siswa dengan uang gedung dapat dilihat pada Gambar 14.

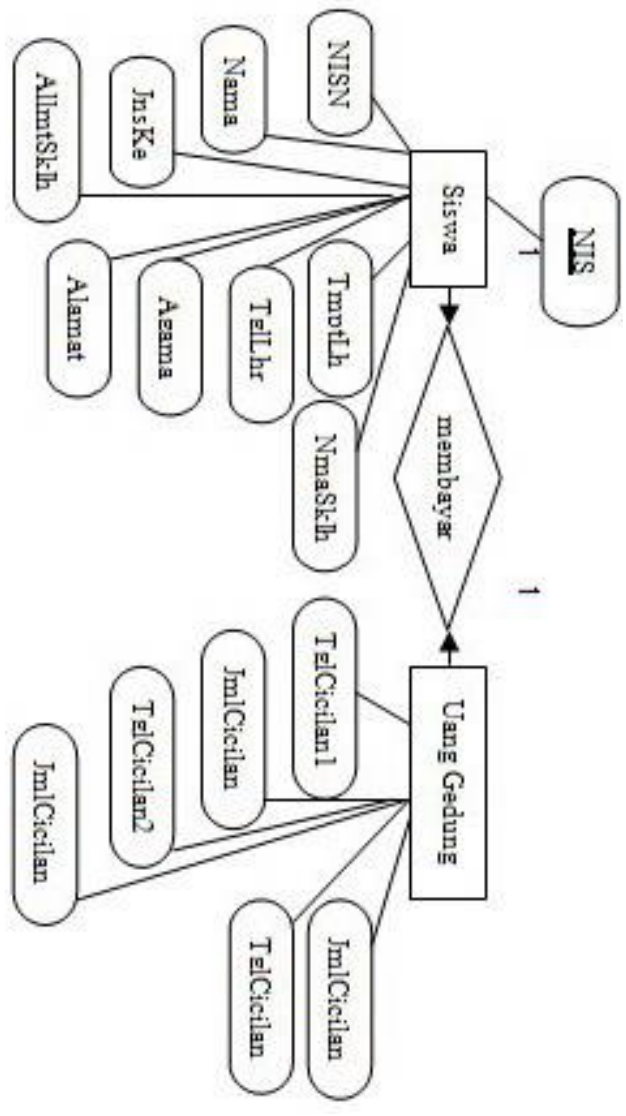

Gambar 14 ERD Siswa dengan Uang Gedung

ERD siswa dengan uang ujian dapat dilihat pada Gambar 15. 


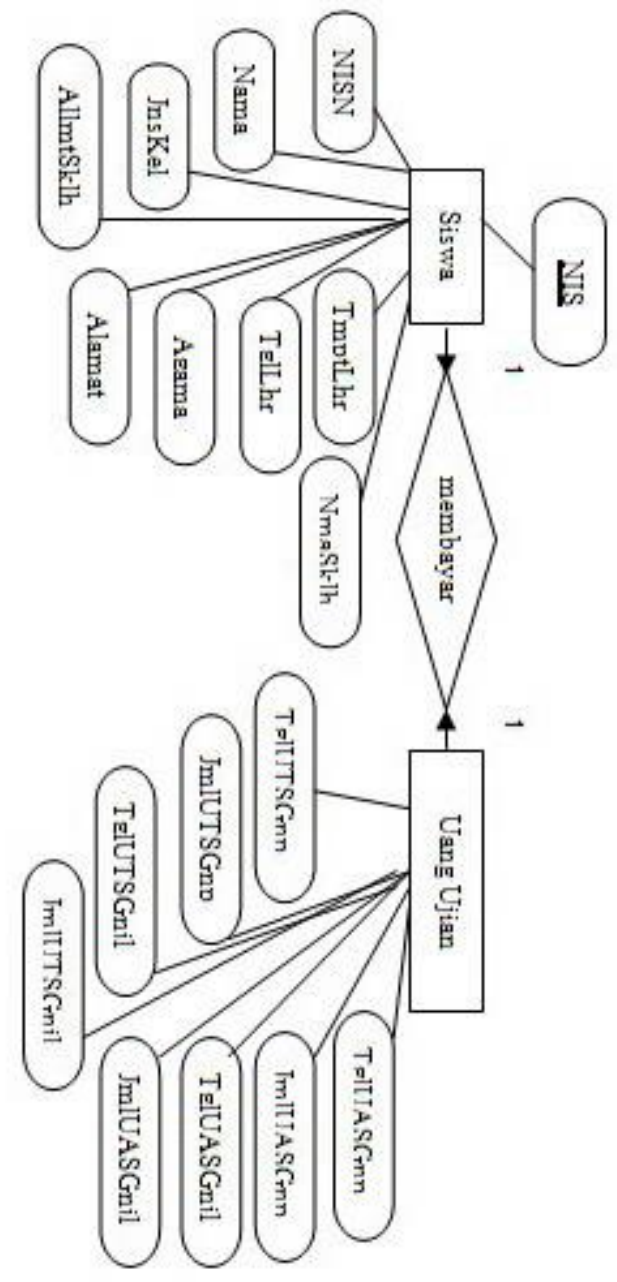

Gambar 15 ERD Siswa dengan Uang

Ujian

\subsubsection{Pembuatan Tabel}

Berdasarkan ERD di atas, maka diperoleh tabel-tabel sebagai berikut :

Tabel 1 Tabel Kelas

\begin{tabular}{|l|l|l|}
\hline Nama Field & Tipe & Size \\
\hline kelas & varchar & 15 \\
\hline Wali_kelas & varchar & 45 \\
\hline Nip_wali & varchar & 20 \\
\hline
\end{tabular}

Tabel 2 Tabel Login

\begin{tabular}{|l|l|l|}
\hline Nama Field & Tipe & Size \\
\hline username & varchar & 20 \\
\hline password & varchar & 30 \\
\hline status & varchar & 15 \\
\hline
\end{tabular}

Tabel 3 Tabel Uang Gedung

\begin{tabular}{|l|l|l|}
\hline Nama Field & Tipe & Size \\
\hline nis & varchar & 15 \\
\hline tglcicilan1 & date & - \\
\hline ncicilan1 & varchar & 11 \\
\hline tglcicilan2 & date & - \\
\hline ncicilan2 & varchar & 11 \\
\hline tglcicilan3 & date & - \\
\hline ncicilan3 & varchar & 11 \\
\hline
\end{tabular}

Tabel 4 Tabel Bagi Kelas

\begin{tabular}{|l|l|l|}
\hline Nama Field & Tipe & Size \\
\hline nis & varchar & 15 \\
\hline kelas & varchar & 8 \\
\hline
\end{tabular}

Tabel 5 Tabel Tahun Ajaran

\begin{tabular}{|l|l|l|}
\hline Nama Field & Tipe & Size \\
\hline thnAjaran & integer & 4 \\
\hline
\end{tabular}

Tabel 6 Tabel SPP

\begin{tabular}{|l|l|l|}
\hline Nama Field & Tipe & Size \\
\hline nis & varchar & 15 \\
\hline juli & date & - \\
\hline agustus & date & - \\
\hline september & date & - \\
\hline oktober & date & - \\
\hline november & date & - \\
\hline desember & date & - \\
\hline januari & date & - \\
\hline februari & date & - \\
\hline maret & date & - \\
\hline april & date & - \\
\hline mei & date & - \\
\hline juni & date & - \\
\hline
\end{tabular}

Tabel 7 Tabel Data Siswa

\begin{tabular}{|l|l|l|}
\hline Nama Field & Tipe & Size \\
\hline nis & varchar & 7 \\
\hline nisn & varchar & 12 \\
\hline nama & varchar & 45 \\
\hline jenisKelamin & char & 1 \\
\hline tptLahir & varchar & 45 \\
\hline tglLahir & date & - \\
\hline agama & varchar & 10 \\
\hline alamat & varchar & 80 \\
\hline
\end{tabular}




\begin{tabular}{|l|l|l|}
\hline nmSekAsal & varchar & 45 \\
\hline almtSekAsal & varchar & 45 \\
\hline thnIjazah & varchar & 4 \\
\hline noIjazah & varchar & 45 \\
\hline tingkat & varchar & 10 \\
\hline tglTerima & date & - \\
\hline nmAyah & varchar & 45 \\
\hline nmIbu & varchar & 45 \\
\hline kerjaAyah & varchar & 20 \\
\hline kerjaIbu & varchar & 20 \\
\hline almtOrtu & varchar & 80 \\
\hline
\end{tabular}

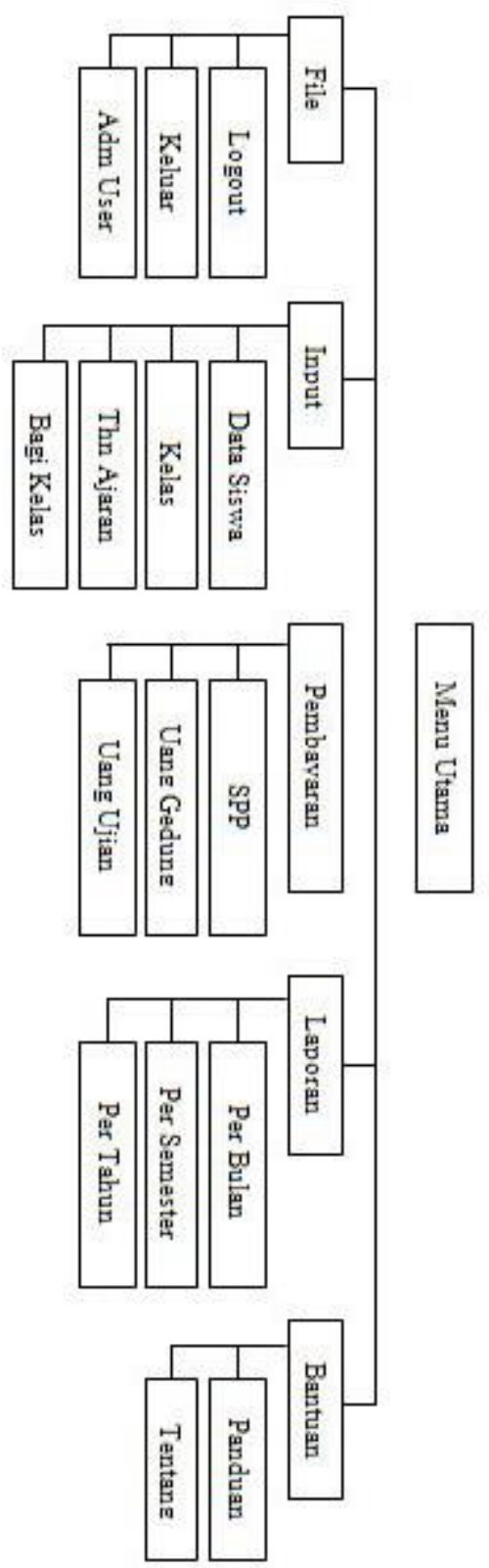

Tabel 8 Tabel Bayar Ujian

\begin{tabular}{|l|l|l|}
\hline Nama Field & Tipe & Size \\
\hline nis & varchar & 15 \\
\hline tglutsgenap & date & - \\
\hline jmlutsgenap & varchar & 11 \\
\hline tglutsganjil & date & - \\
\hline jmlutsganjil & varchar & 11 \\
\hline tgluasgenap & date & - \\
\hline jmluasgenap & varchar & 11 \\
\hline tglutsganjil & date & - \\
\hline jmluasganjil & varchar & 11 \\
\hline
\end{tabular}

Tabel yang dihasilkan tidak memperlihatkan masih adanya redundansi oleh karena itu dalam penelitian ini tidak dilakukan normalisasi basis data.

\subsection{Perancangan Tingkatan Hak Akses Pengguna}

Hak akses pengguna dibagi menjadi tiga tingkatan yaitu head admin, admin dan pengguna biasa. Head admin adalah hak akses untuk kepala tata usaha, hak akses admin dipergunakan untuk petugas di tata usaha sedangkan pengguna biasa dipergunakan oleh kepala sekolah. Perbedaan akses menu masing-masing tingkatan dapat dilihat di Gambar 16, Gambar 17 dan Gambar 18. 


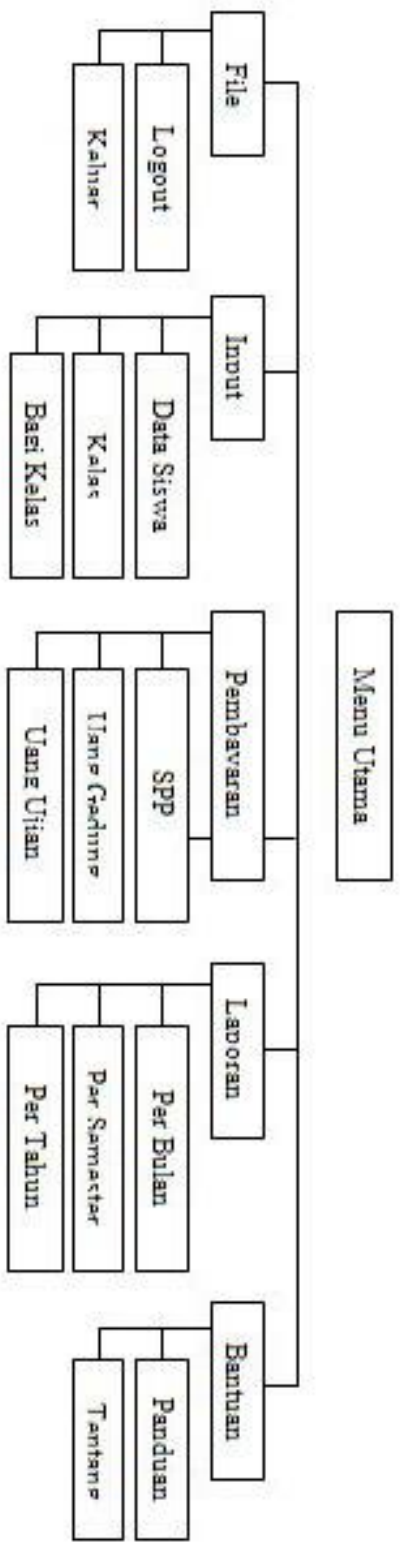

Gambar 17 Hak akses untuk admin

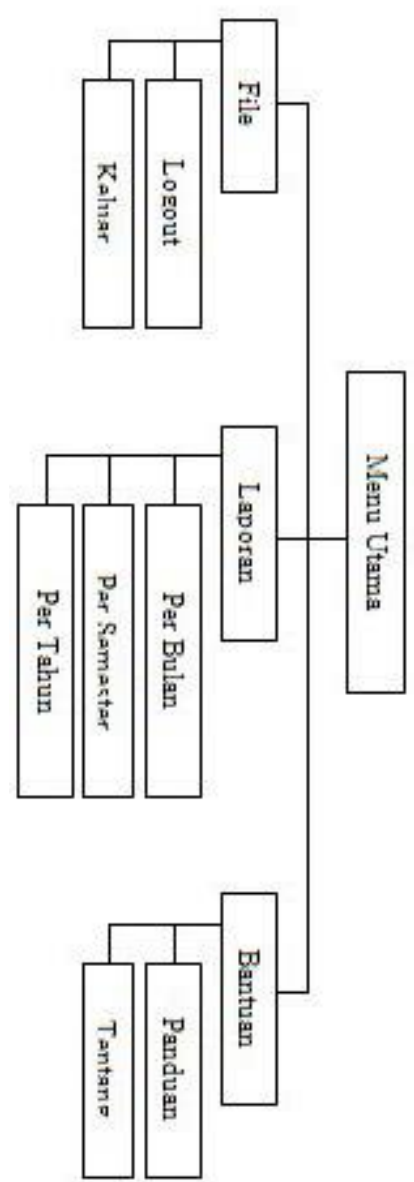

Gambar 18 Hak akses untuk pengguna biasa

\subsection{Pengaturan Jaringan}

Topologi jaringan yang dipergunakan untuk mengimplementasikan aplikasi sistem pembayaran di SMA Yos Sudarso adalah topologi star.

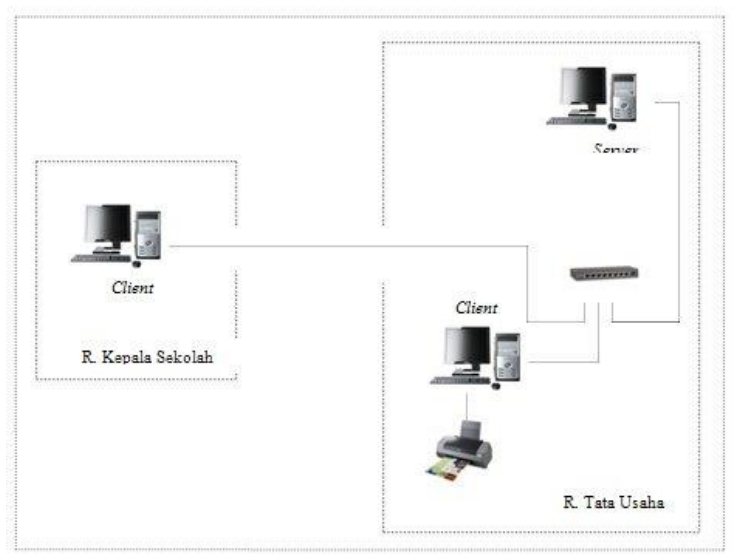

Gambar 19 Topologi jaringan yang diterapkan 


\section{Pengujian}

Pengujian dilakukan menggunakan metode black box testing dimana pengujian hanya untuk menguji apakah fungsi-fungsi yang ada di dalam aplikasi dapat berjalan dengan semestinya tanpa mempedulikan proses internal dalam kode (Galin, 2004). Aplikasi dijalankan secara client server kemudian menu untuk setiap hak akses dijalankan untuk mengetahui apakah semua menu sudah dapat berfungsi. Beberapa tampilan menu dapat dilihat pada Gambar berikut.

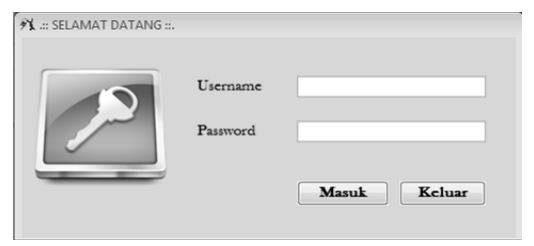

Gambar 20 Menu login

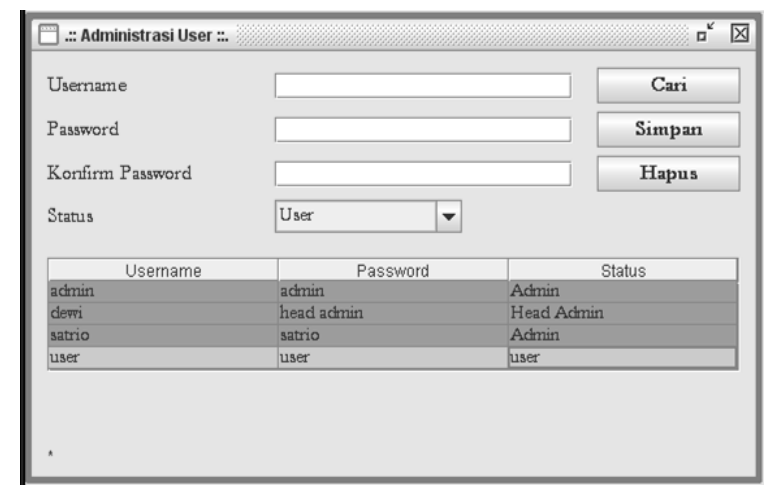

Gambar 21 Menu administrasi user

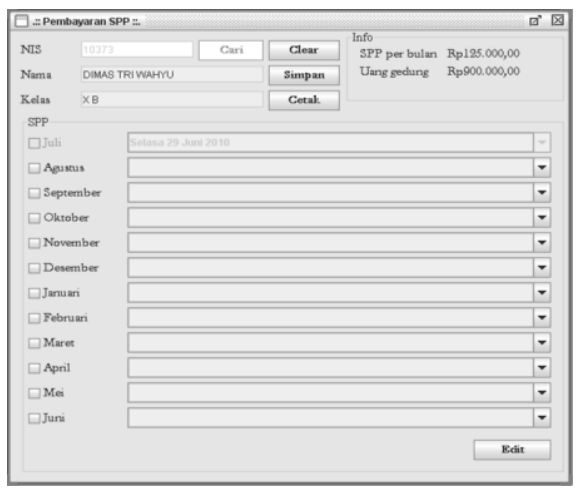

Gambar 22 Menu Pembayaran SPP

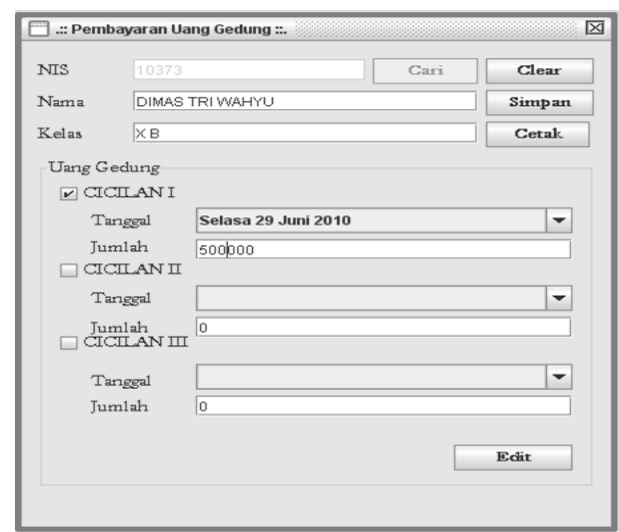

Gambar 23 Menu Pembayaran Uang Gedung

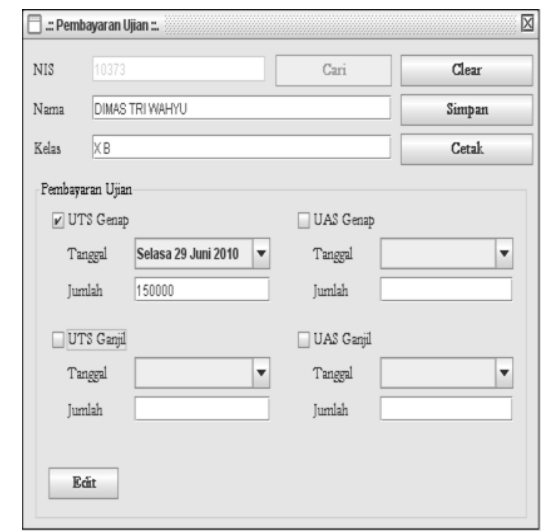

Gambar 24 Menu Pembayaran Ujian

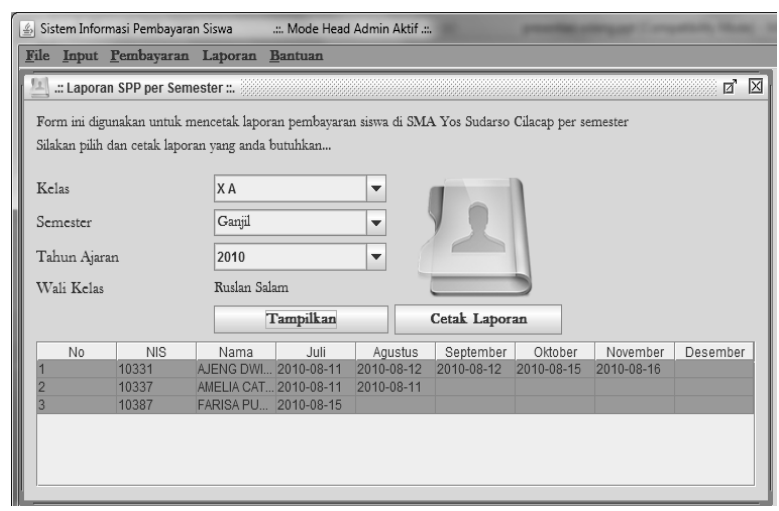

Gambar 25 Menu Laporan SPP per semester

\subsection{Kesimpulan}

Dari hasil pengujian, aplikasi sistem pembayaran telah dapat berjalan sesuai dengan fungsi-fungsi yang direncakan. Aplikasi pembayaran sekolah yang telah dibuat masih memiliki kekurangan yaitu belum adanya kemampuan backup data 
secara otomatis, tetapi masalah ini dapat diatasi dengan menggunakan aplikasi lainnya. Untuk pengembangan selanjutnya diharapkan kekurangan ini dapat dilengkapi, sehingga aplikasi ini dapat mem-backup data secara otomatis.

\section{Daftar Pustaka:}

Galin, Daniel. 2004. Software Quality Assurance. Pearson Education, L.td.

Hariyanto, Bambang. 2007. Esensi-esensi Bahasa Pemrograman JAVA Edisi 2. Bandung. Penerbit Informatika.

Kadir, Abdul. 2008. Tuntunan Praktis Belajar Database Menggunakan MySQL. Yogyakarta. Penerbit Andi.

Sommerville. 2009. Software Engineering: Eight Edition. Pearson Education. 